\title{
What do we call Adaptive Management? A general characterization from a global sample
}

\author{
Tiscar Espigares, Noelia Zafra-Calvo and Miguel Á. Rodríguez
}

Espigares, T., Zafra-Calvo, N. and Rodgríguez, M. Á. 2008. What do we call Adaptive Management? A general characterization from a global sample. - Web Ecology 8: 1-13.

\begin{abstract}
This study presents a characterisation of the implementation of Adaptive Management (AM) from the analysis of 35 projects around the world. Our results reveal that AM projects are usually aimed at ecosystem management, conservation and restoration. Also, they mainly act upon forest or epicontinental water ecosystems and their goal is generally species exploitation and in most cases these projects act at a local scale. From a methodological point of view, most AM cases use an active approach and monitoring programs and were at the phase of problem identification. We found differences in the implementation of AM between developed and developing countries that were present in our samples in the following way: AM projects in developed countries were typically carried out by state agencies, and focused on solving problems concerning epicontinental waters and the public use of ecosystems. They had the support of national funds and used modelling techniques. In contrast, the AM projects from developing countries were mainly aimed at the conservation of natural protected areas and at the mitigation of environmental impacts derived from mining activities. The financial support of these projects was frequently provided by international organizations, and the use of modelling techniques was uncommon. For a better exploitation of all the possibilities of AM, we suggest the use of criteria to be customized to the specific needs of the socio-economic reality of every country and to monitor the results at a global scale to continuously improve this practice.
\end{abstract}

T. Espigares, (mtiscar.espigares@uah.es), N. Zafra-Calvo, M. A. Rodgríguez,Dept of Ecology, Univ. of Alcalá, ES-28871, Alcalá de Henares, Spain.

The current environmental crisis is one of the main challenges faced by humankind, because many goods and services that contribute to social welfare are inextricably linked to the naturalness or semi-naturalness of ecosystems (Costanza et al. 1997). This crisis is particularly difficult to face for developing countries because they typically have valuable natural and environmental resources, but scarce economic means to preserve them. Two key means to face this challenge have been the creation of effective networks of protected natural areas, and the design of management strategies of natural and socio-economic systems that may make management compatible with the preservation of natural resources. Although several of these management strategies have been devised and implemented, the studies that have analyzed their effectiveness show unequal results (Hering 2003, Dichmont et al. 2006). In the case of protected areas, there is a wide agreement in that their delimitation, management and funding are frequently inappro- 
priate in several parts of the world, including Europe (Oldfield et al. 2004), Latin America (Powell et al. 2000, Armenteras et al. 2003, Cantú et al. 2004), Asia (Latif Khan 1997, Jepson et al. 2002), and Africa (Wilkie et al. 2001, Blom et al. 2004, De Klerk et al. 2004, Struhsaker et al. 2005, Burgess et al. 2005). In fact, this situation emphasizes the need to continue developing and improving conservation and management strategies that are suited to each socio-economic reality within the context of sustainable development.

The growing sophistication of the methodologies used for the management of ecosystems in recent years has crystallized in the new paradigm of Adaptive Management (AM) (Holling 1978). The most remarkable feature of this approach is its ability to learn from the enormous uncertainties that management is usually confronted with, in a process in which management is designed to gain information from ecosystems, in what has usually been called 'learning by doing' (Walters and Holling 1990). These uncertainties derive from our scant knowledge and understanding of the complexities of most ecosystems and their interactions with socio-economic systems. As defined by Nyberg (1999), AM "is a systematic process for continually improving management policies and practices by learning from the outcomes of operational programs (...). It employs management programs that are designed to experimentally compare selected policies or practices, by evaluating alternative hypotheses about the system being managed". In short, AM incorporates research and experimentation in the conservation actions, emphasizes social participation and the institutional framework within the socio-economic context, and enables, in a systematic and rigorous way, to learn from the results of management and to incorporate this knowledge to devise future actions (British Columbia Forest Service 1997).

The broadly accepted methodological procedure of AM involves five steps, with the desirable incorporation of social participation: (1) identification of managing problems usually carried out by modelling the functioning of the system under several feasible scenarios of management, (2) design and (3) implementation of the Management Plan and Monitoring Program, the latter being a core element in the AM since it allows for a permanent adjustment of the management strategy based on its results, (4) management assessment, and (5) management adjustment.

Nowadays, AM is widely used to manage natural resources, ecological and social systems, and protected natural areas. However, despite the promising expectations generated at the beginning, recent studies have shown some weaknesses in the actual implementation of AM which confirm that the harvested results are far from those initially expected (McLain and Lee 1996, Lee 1999, Gregory et al. 2006). Besides the complexity to combine scientists, policy makers and developers needs, another weak point of AM application is the multiple interpretations of this strategy. Indeed, far from being a straight forward unique way of making management, it includes a whole array of practices that emphasize different aspects of the methodological process. In fact, although monitoring is the distinctive feature of AM for most authors (Allen et al. 2001, Campbell et al. 2002), some others stress the importance of other aspects of the methodology such as the process of generating and assessing scenarios throughout modelling (Carpenter et al. 1999, Walters et al. 2000), or social participation (Shindler and Cheek 1999).

Bearing this in mind, it is not surprising to find a scarcity of works that analyze the effectiveness of AM implementation in the world. Most of the antecedents are studies that evaluate the efficiency and limitations (Walters 1997) of AM in individual cases (Pinkerton 1999, Gray 2000) or, at most, three cases together (McLain and Lee 1996, Gilmour et al. 1999). In any case, the lack of a global perspective to tackle the AM situation worldwide is remarkable. The present work contributes to the discussion with a diagnosis of the kind of practices that are carried out in the world labelled as AM, without aiming at any evaluation of their effectiveness. The objective of our study is to make a general characterization of the management practices whose implementers call AM, paying special attention to geographic, ecological, socioeconomic and methodological features. Therefore, the aim of the present paper is twofold: firstly, to identify the main applications of the strategy of Adaptive Management in use, and secondly, to establish whether ecological and socio-economic factors have some effect in determining the kind of management that is applied. This will offer a description of the state of the art of AM in the world.

\section{Material and methods}

The study involved 35 study cases of AM, which were obtained by reviewing the scientific literature during 19942004 as well as other documents (e.g. project reports) backed up by well-known institutions (Table 1). Only the cases in which the authors explicitly used the term "Adaptive Management" to describe their activities were selected. Each case was examined to obtain 16 variables that reflected its geographical, ecological, and socio-economic contexts, the actors supporting and undertaking the AM (funding and implementing organizations), and also the major methodological features of the practices it involved (Table 2). In those cases in which the bibliography did not supply all the data required for the study, we contacted the authors and asked for additional information.

A non-metric multidimensional scaling (NMDS) analysis was first performed on the matrix of the study cases and variables to explore overall differences among cases. Since only two variables were quantitative, Human Development Index (HDI), and Gross National Product (GNP) (Table 2), a second NMDS was performed without these variables to avoid their overweight in the ordination re- 
sults. For both analyses, distances were measured on the basis of Sorensen index. The results of the two analyses clearly differentiated two groups of AM study cases (Results), which prompted us to further investigate their relationships with each of the categorical variables using $\chi^{2}$ tests of bivariate association. NMDS analyses were performed with PC-Ord for Windows Multivariate Analysis of Ecological Data ver. 4.0. (McCune and Mefford 1999), and for $\chi^{2}$ tests we used Statistica Software ver. 6.0. (StatSoft 2003).

\section{Results}

Among the 35 study cases analysed, 21 belonged to developed countries while 14 took place in developing ones. As there is no established convention for the designation of 'developed' and 'developing' countries in the United Nations system, we considered as developed those countries within the upper third in the ranking of countries according with HDI (UNDP 2002). Figure 1a shows the two axes solution of the NMDS performed including all vari-

a)

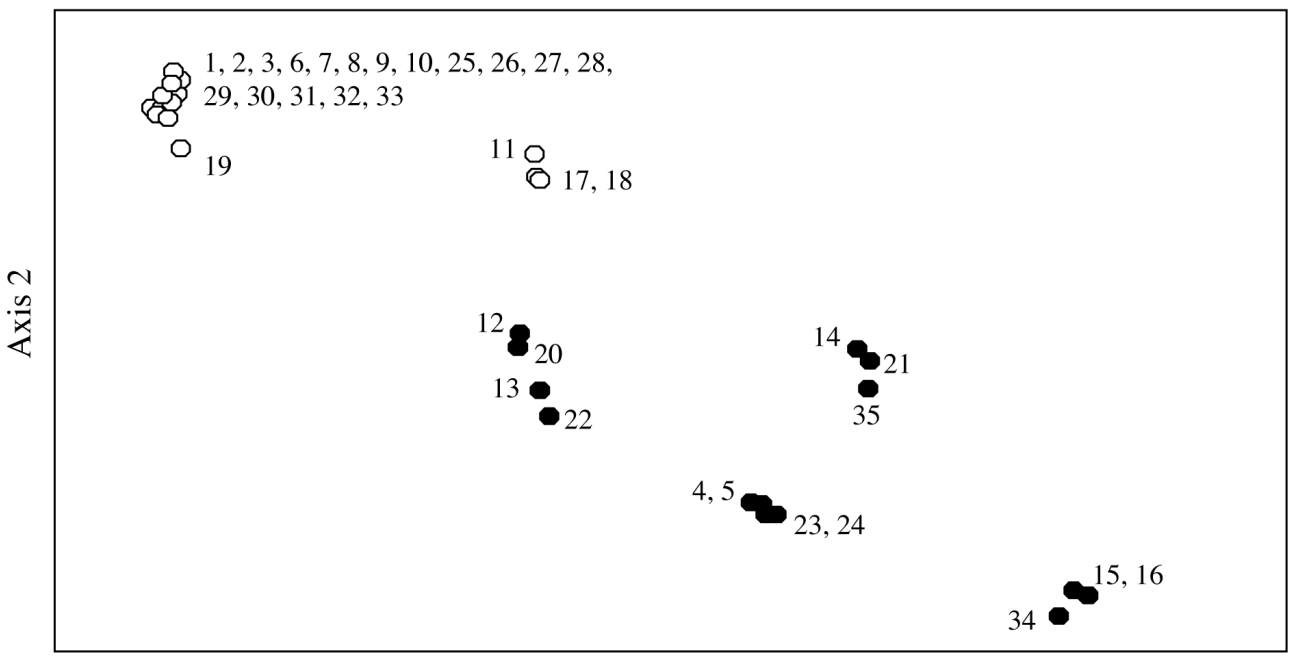

Axis 1

b)

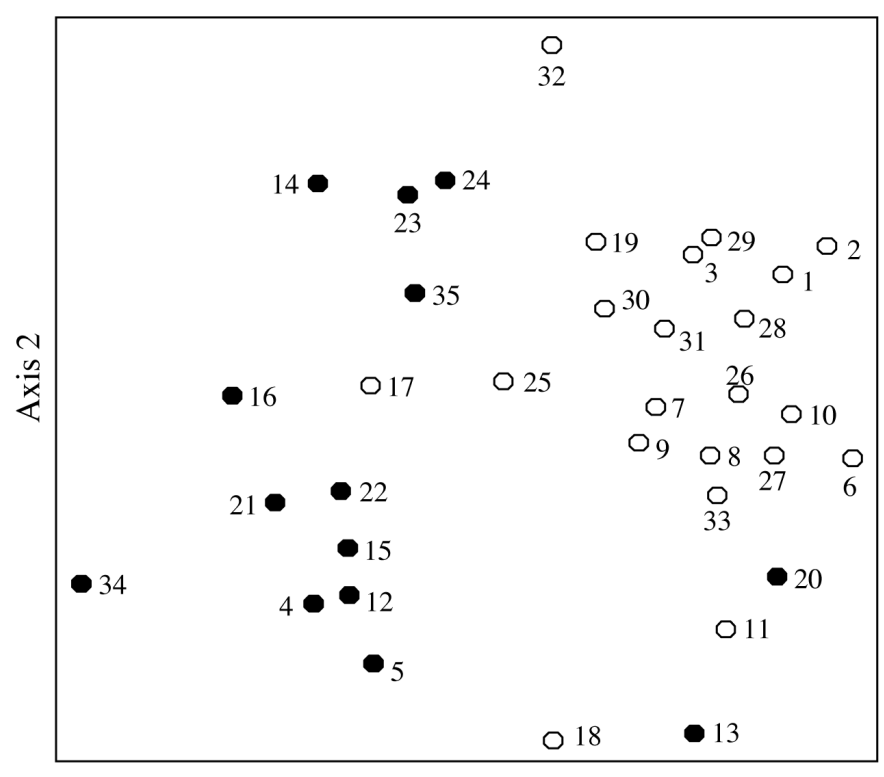

Axis 1

Fig. 1. Overall differences among the $35 \mathrm{AM}$ study cases according to the NMDS analysis performed with all variables (a) and after excluding the quantitative variables (b). The numbers in the ordination plane indicate the study cases as in Table 1 . White circles: developed countries; black circles: developing countries. 


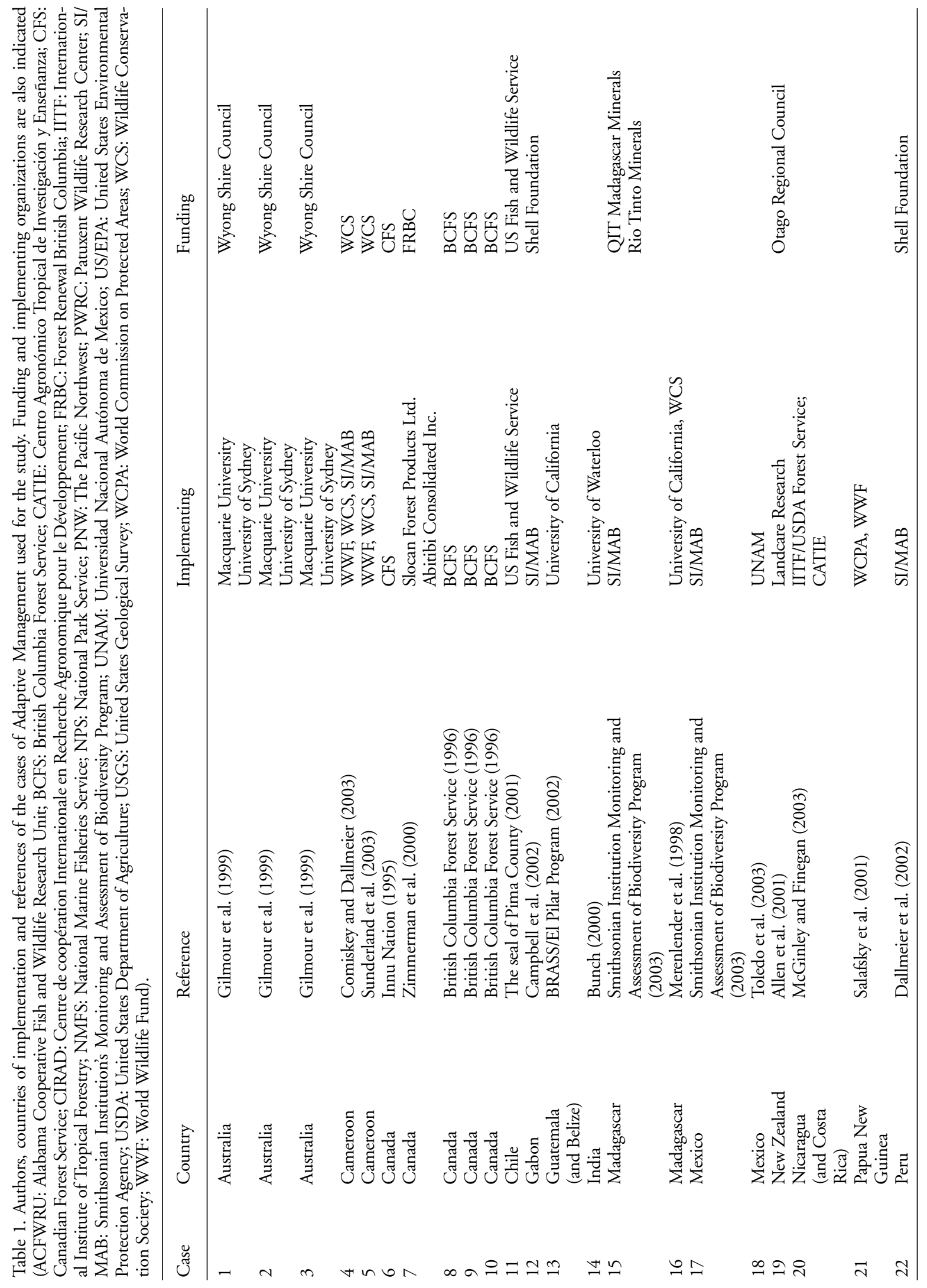




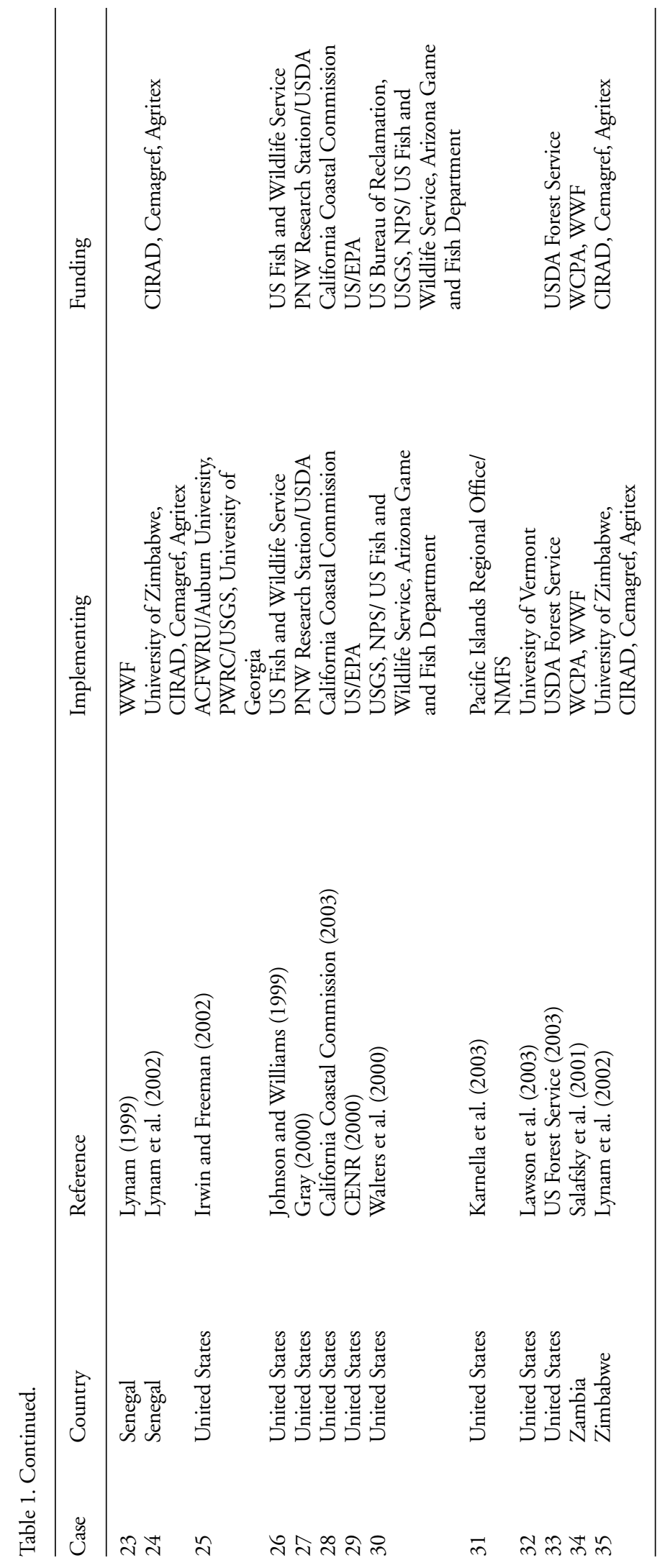


Table 2. Variables used for the study of characterization of adaptive management (Q: quantitative variable, C: categorical variable).

\begin{tabular}{|c|c|c|c|c|}
\hline & Variable & Type & Categories & Description \\
\hline \multirow[t]{2}{*}{ Socioeconomic } & $\begin{array}{l}\text { Human } \\
\text { Development } \\
\text { Index (HDI) }\end{array}$ & Q & & $\begin{array}{l}\text { According to UNDP } \\
(2002)\end{array}$ \\
\hline & $\begin{array}{l}\text { Gross } \\
\text { National } \\
\text { Product } \\
\text { (GNP) }\end{array}$ & Q & & $\begin{array}{l}\text { According to UNDP } \\
(2002)\end{array}$ \\
\hline \multirow[t]{5}{*}{ Descriptive } & Stage & $\mathrm{C}$ & $\begin{array}{l}\text { Proposal } \\
\text { Problem identification } \\
\text { Implementation of the } \\
\text { management plan } \\
\text { Monitoring } \\
\text { Full cycle }\end{array}$ & $\begin{array}{l}\text { Stage of development } \\
\text { of the AM }\end{array}$ \\
\hline & Domain & $\mathrm{C}$ & $\begin{array}{l}\text { Polar } \\
\text { Humid temperate } \\
\text { Dry } \\
\text { Humid tropical }\end{array}$ & $\begin{array}{l}\text { Domain in which AM } \\
\text { is taking place according } \\
\text { to Bailey (1989) }\end{array}$ \\
\hline & $\begin{array}{l}\text { Type of } \\
\text { ecosystem }\end{array}$ & $\mathrm{C}$ & $\begin{array}{l}\text { Forest } \\
\text { Savannah } \\
\text { Grassland } \\
\text { Epicontinental waters } \\
\text { Shoreline/marine ecosystems }\end{array}$ & $\begin{array}{l}\text { Ecosystem in which } \\
\text { AM is taking place }\end{array}$ \\
\hline & Scale & $\mathrm{C}$ & $\begin{array}{l}\text { Local } \\
\text { Regional } \\
\text { International }\end{array}$ & $\begin{array}{l}\text { Scale of application } \\
\text { of the AM }\end{array}$ \\
\hline & $\begin{array}{l}\text { Degree of } \\
\text { protection }\end{array}$ & C & $\begin{array}{l}\text { Protected area } \\
\text { Not protected area }\end{array}$ & $\begin{array}{l}\text { According to The } \\
\text { World Conservation } \\
\text { Union (IUCN 1994) }\end{array}$ \\
\hline \multirow[t]{2}{*}{ Actors } & $\begin{array}{l}\text { Funding } \\
\text { organization }\end{array}$ & $\mathrm{C}$ & $\begin{array}{l}\text { Government } \\
\text { NGO's } \\
\text { Universities/research institutions } \\
\text { Private } \\
\overline{\text { National }} \\
\text { International }\end{array}$ & \\
\hline & $\begin{array}{l}\text { Implementing } \\
\text { organization }\end{array}$ & $\mathrm{C}$ & $\begin{array}{l}\text { Government } \\
\text { NGO's } \\
\text { Universities/research institutions } \\
\text { Private } \\
\text { National } \\
\text { International }\end{array}$ & \\
\hline $\begin{array}{l}\text { Management } \\
\text { context }\end{array}$ & Motivation & $\mathrm{C}$ & $\begin{array}{l}\text { Civil engineering } \\
\text { Pollution } \\
\text { Mining activities } \\
\text { Tourism } \\
\text { Species exploitation } \\
\text { Local development }\end{array}$ & $\begin{array}{l}\text { Reason that motivates } \\
\text { the need of the AM }\end{array}$ \\
\hline
\end{tabular}


Table 2. Continued.

\begin{tabular}{|c|c|c|c|c|}
\hline & Variable & Type & Categories & Description \\
\hline & Aim & $\mathrm{C}$ & $\begin{array}{l}\text { Ecosystem management } \\
\text { Conservation } \\
\text { Restoration/mitigation }\end{array}$ & Purpose of the AM \\
\hline & Target & $\mathrm{C}$ & $\begin{array}{l}\text { Water } \\
\text { Forests } \\
\text { Diversity } \\
\text { Agriculture } \\
\text { Fisheries } \\
\text { Public use } \\
\text { Historic-cultural } \\
\text { Hunting } \\
\text { Land management }\end{array}$ & $\begin{array}{l}\text { Resource on which } \\
\text { AM is implemented }\end{array}$ \\
\hline \multirow[t]{4}{*}{ Methodology } & $\begin{array}{l}\text { Type of } \\
\text { Adaptive } \\
\text { Management }\end{array}$ & $\mathrm{C}$ & $\begin{array}{l}\text { Active (management actions are } \\
\text { deliberately designed as } \\
\text { management experiments, to } \\
\text { discriminate the best between } \\
\text { various alternative hypotheses) } \\
\text { Passive (a management model - } \\
\text { considered correct - is } \\
\text { constructed on the basis of } \\
\text { historical data) }\end{array}$ & $\begin{array}{l}\text { According to Walters } \\
\text { and Holling (1990) }\end{array}$ \\
\hline & Participation & $\mathrm{C}$ & $\begin{array}{l}\text { Local population } \\
\text { Experts } \\
\text { No participation }\end{array}$ & $\begin{array}{l}\text { Actors involved in } \\
\text { the elaboration of the } \\
\text { AM }\end{array}$ \\
\hline & Modelling & $\mathrm{C}$ & $\begin{array}{l}\text { Presence } \\
\text { Absence }\end{array}$ & \\
\hline & Monitoring & $\mathrm{C}$ & $\begin{array}{l}\text { Presence } \\
\text { Absence }\end{array}$ & \\
\hline
\end{tabular}

ables. This ordination exhibits a very low stress (0.06), which indicates that the overall differences among the study cases are reasonable depicted by the two axes. The first axis is strongly correlated with the HDI and GNP of the countries $(r=-0.98$ and -0.92 , respectively; $p<0.05$ in both cases), suggesting that the main differences among the AM study cases are conditioned by the socio-economic statuses of the countries in which it is applied. There is, however, a caveat with regard to these results. Since the only two quantitative variables included in the data where precisely HDI and GNP, the ordination result could be reflecting the likely stronger weight of these variables on the analysis, and not real management differences among study cases. Accordingly, we repeated this analysis with the exclusion of HDI and GNP from the data, but again the results clearly supported the previous findings. Albeit the new ordination plane exhibited a slightly poorer fit (stress value $=0.27$ ), it reflected the same overall trends (Fig. 1b). In other words, the study cases from developed and developing countries appeared clearly separated in the ordina- tion plane, and the correlations of the first ordination axis with HDI and GNP were also high $(r=0.82$ and 0.73 , respectively; $\mathrm{p}<0.05$ ). Thus, the data indicate that developed and developing countries differ with regard to the characteristics of the AM being performed in each case. To delve into this result, several $\chi^{2}$ tests were performed to explore the existence of significant differences between both groups of cases for each of the variables under analysis.

Regarding the stage of development of the AM we found that most of the study cases (53\%) were at the phase of problem identification, and only $9 \%$ of them finished the full cycle. Although we did not observe significant differences between developed and developing countries, the higher number of cases found at the implementation or monitoring stages in developed countries may reflect the general delay that developing countries experienced in the use of this management practice.

Regarding the geography, we found that AM is being applied in all the ecological domains, with a clear prefer- 
ence for those with higher human population (humidtemperate and humid-tropical) which covered $74 \%$ of the cases. Obvious differences $\left(\chi^{2}=27.58, \mathrm{DF}=3, \mathrm{p}<0.001\right)$ were found in the ecological domain between developed and developing countries, thus reflecting their unequal geography: developed countries mainly concentrate in temperate areas while developing countries broadly coincide with the tropics.

When we focus on the type of ecosystems subjected to AM in the world, we find that forests and epicontinental waters are the most common, covering together $73 \%$ of all cases. Then, savannahs and grasslands represent $10 \%$ of the cases each, and, finally, the less represented are shoreline and marine ecosystems, with only $7 \%$ of the cases. No significant differences between developed and developing countries were found when we did the analysis with the five categories indicated in Table 2. However, when we grouped these categories in only two, aquatic (including epicontinental waters and shoreline/marine ecosystems) and terrestrial (including forest, savannah and grasslands), we found significant differences between developed and developing countries $\left(\chi^{2}=6.56, \mathrm{DF}=1, \mathrm{p}<0.02\right)$. Most of the cases of AM in developing countries act upon terrestrial ecosystems (87\%) while in developed countries AM projects involved terrestrial and aquatic ecosystems in a very similar proportion ( $46 \%$ vs $54 \%$ respectively)., The scale of application of the AM projects was local (80\%) in most of the cases, and this pattern applied to both developed and developing countries.

Although most of AM cases took place in non protected areas (69\% of all cases), the percentage of AM cases acting in protected areas was higher in developing countries than in developed ones ( $46.6 \%$ vs $19.0 \%$ ), though this difference was only marginally significant $\chi^{2}=3.15, D F=1, p$ $<0.1)$.
When we focus on the actors involved in the AM, we find clear differences between developed and developing countries. While in developed countries $94.74 \%$ of the $\mathrm{AM}$ cases are funded by national institutions, only $16.67 \%$ are in developing ones $\left(\chi^{2}=15.24, \mathrm{DF}=1, \mathrm{p}<\right.$ 0.001 ). A more detailed analysis of the nature of funding institutions revealed that Governments are the funding entities par excellence in developed countries $\left(\chi^{2}=4.44\right.$, $\mathrm{DF}=1, \mathrm{p}<0.03)$, while in developing countries, other institutions as NGO's sponsor almost half of the AM cases.

The profile of the institutions that implement AM followed a similar pattern to funding organizations. In this case, national organizations implement most of the AM projects in both developed and developing countries (90\% and $62 \%$ respectively), although a conspicuous part of the projects $(38 \%)$ in developing countries is still implemented by international institutions $\left(\chi^{2}=3.18, \mathrm{DF}=1, \mathrm{p}<\right.$ 0.1 ). Significant differences were found in the kind of implementing institutions between developed and developing countries $\left(\chi^{2}=10.82, \mathrm{DF}=3, \mathrm{p}<0.02\right)$ : while in developed countries, again, Governments are the main implementers ( $78 \%$ of the cases); in developing countries NGO's and research institutions are responsible for the implementation of $75 \%$ of the AM projects.

In terms of the context of the AM, we find different motivations for AM projects, being the most frequent the species exploitation, that motivates $35 \%$ of the AM cases in both developed and developing countries (Fig. 2). However, distinct differences between developed and developing countries were observed $\left(\chi^{2}=14.55, \mathrm{DF}=5, \mathrm{p}<0.02\right)$. Among the six categories of motivation we identified in Table 2 (civil engineering, pollution, mining, tourism, species exploitation and local development), the first three show the highest differences between developed and devel-

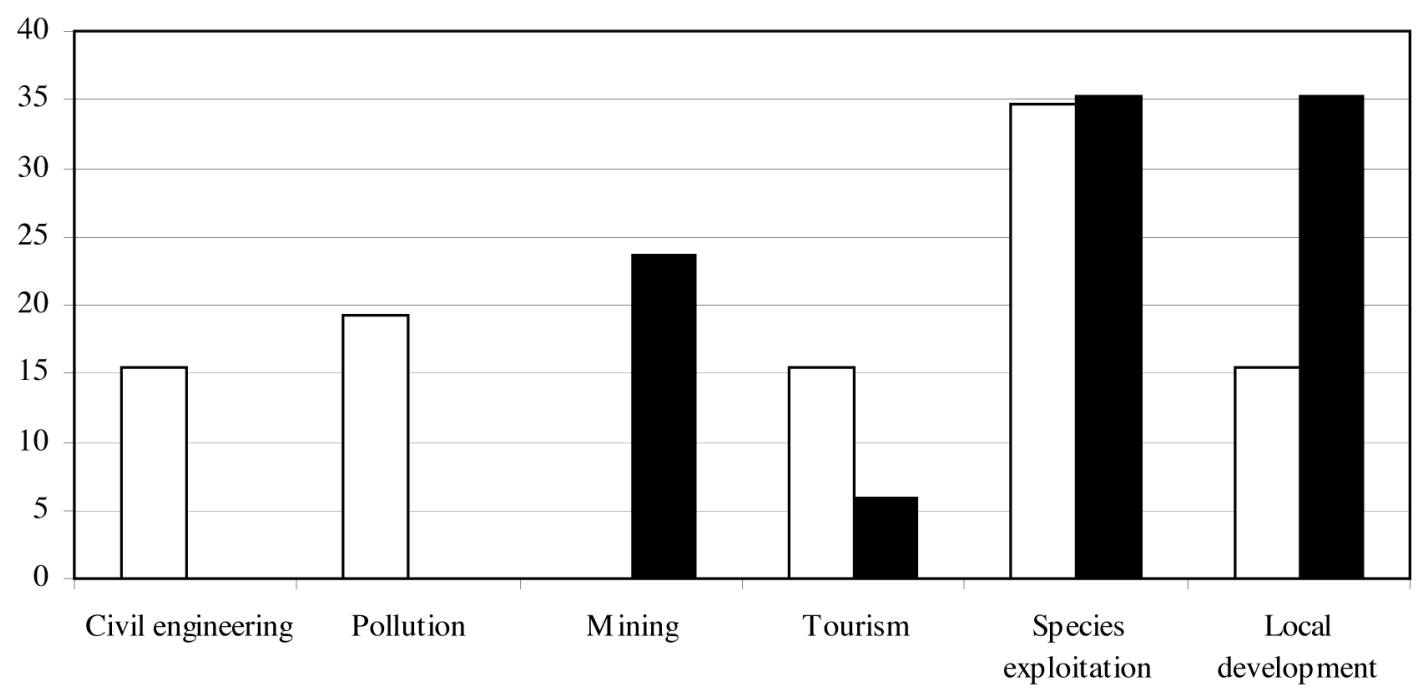

Fig. 2. Frequency (\%) of motivation of the AM cases. In black, developing countries. In white, developed countries. 
oping countries. Civil engineering and pollution motivated one third of the AM projects in developed countries and did not motivate any in less developed ones. As a contrast, mining activities originated the fourth part of the AM projects carried out in developing countries and did not originate any in developed ones (Fig. 2).

Regarding the principal aim of the AM, we observed that, at a global scale, a third of the projects were directed to ecosystem management, another third to conservation practices and the final third to restoration/mitigation issues. No significant differences were found between developed and developing countries. When we looked at the target of the AM, that is, the resource on which AM projects are implemented, we observed that $28 \%$ of the study cases deal with diversity questions, which constitute the more frequent target. Anyway, AM cases implemented in the world involved a wide variety of situations, with projects focusing not only on diversity, but also on water, forests, agriculture, fisheries, etc (Table 2). When we analysed each category in detail, we only found significant differences between developed and developing countries when the target is public use $\left(\chi^{2}=4.83, \mathrm{DF}=1, \mathrm{p}<0.02\right)$. While in developed countries public use was the target of $12 \%$ of the AM cases, in developing countries this target did not exist.

Finally, we analysed the characteristics of AM projects in the world according to general aspects of their methodology. Most of the AM projects (70\%) use active management, and the same pattern was found in both developed and developing countries. Also, monitoring processes were used in more than $90 \%$ of the AM cases in all countries. Modelling techniques were used in $65 \%$ of the AM projects, but preferably in developed countries $\left(\chi^{2}=5.72\right.$, $\mathrm{DF}=1, \mathrm{p}<0.02)$, where the percentage of their use reached $83 \%$ of the cases. When we analysed the participation of local population and experts in the AM process, we found that in $51 \%$ of the study cases, both local population and experts intervened. Marginal differences between developed and developing countries were found $\left(\chi^{2}=5.39\right.$, $\mathrm{DF}=2, \mathrm{p}<0.1)$, as local population intervention was higher in developing countries while experts intervention was more frequent in developed ones (Fig. 3).

\section{Discussion}

The analysis of a series of AM cases from a global sample allowed us to obtain a general picture of what it is being performed in the world under the denomination of Adaptive Management. In general terms, we can state that when we speak of AM we are referring to management models broadly used all over the world, covering all ecological domains but more frequently in the more populated areas. Also, AM projects are usually aimed at ecosystem management, conservation and restoration/mitigation practices. They mainly act upon forest or epicontinental water eco-

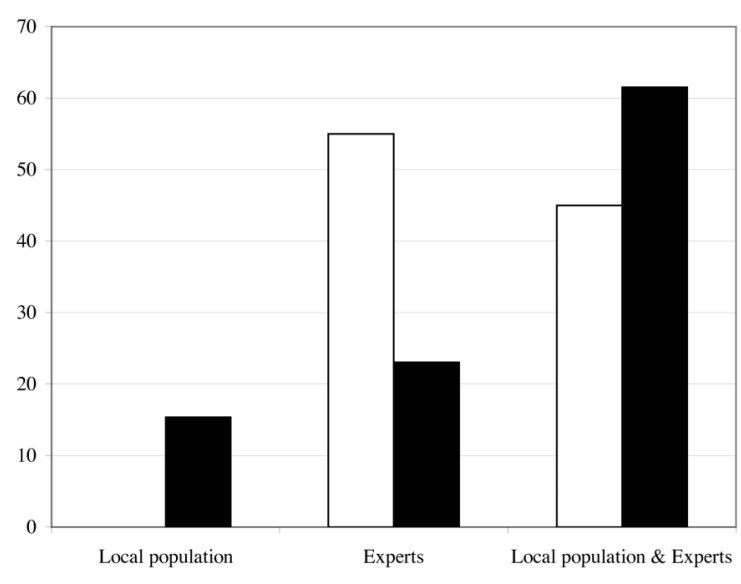

Fig. 3. Participation of local population and experts in AM. In black, developing countries. In white, developed countries (in $\%)$.

systems, and are motivated by a wide variety of circumstances in which species exploitation stand out. In most cases these projects act at a local scale. Within our sample, most of the AM projects executed in developed countries take place in non-protected areas, while in developing countries many AM projects manage the diversity of protected areas. From a methodological point of view, most AM cases use an active approach and monitoring programs; the joint intervention of local population and experts is widely used, but local population intervention alone is more frequent in the developing countries of our sample. Finally, modelling techniques are widely present, especially in the AM cases from developed countries. Most of the analysed cases were at the phase of problem identification, what may reflect the early stage in which AM practices are at a global scale. Although some authors as Gregory (2006) have highlighted the multiple interpretations of AM, our results show that implemented practices labelled as AM share a common methodological scheme, at least in the essential issues like monitoring, active management approach, local population and experts participation and modelling techniques.

The multivariate analyses of the cases under study also allowed us to identify the factors that most condition the type of AM that is being carried out. As Fig. 1 shows, the level of economic development of the countries seems to determine the profile of the AM implemented, so we can distinguish two major trends in the practice of AM in our global sample: whether applied in developed or in developing countries. Anyway, these differences do not cancel the many similarities that, especially in the methodological aspects, we have found in all AM cases, independently of the country where they were implemented.

The similarities found in the methodological features of AM applied all over the world are very important as they 
guarantee a unique general scheme of application of this practice, no matter the geographical factor. For example, monitoring is considered an essential component in AM as it reduces the uncertainty in the management and permits to adjust it within an adaptive process. Also, participation of both local population and experts is well represented (Fig. 3), although the unique participation of experts is more common in developed countries and only local population participation is more frequent in developing ones. Local participation is a crucial element in the practice of AM (Allen 1997, Allen et al. 2001, Shindler and Cheek 1999), and, as McLain and Lee (1996) state, the fluency of communication between scientific knowledge, politicians and management professionals should be promoted to design feasible management plans. The fact that the participation of the local population prevails in developing countries may be due to the fact that AM in developed countries basically relies upon experts from State institutions, whereas in developing countries it is usually performed by foreign organizations that need to count on the local population to implement their projects. The only methodological feature in which we found significant differences between developed and developing countries in our sample was the use of modelling and potential scenarios techniques, significantly more widespread in developed countries. The fewer financial and technological resources in developing countries, and the usually reduced knowledge of the environment where management is applied to, may be the main reason for this difference. At this point, it is not easy to interpret the influence that this methodological difference may have on AM practice in both types of countries, especially if we consider the debate on the importance of modelling techniques in AM. In fact, some authors believe that modelling is a key element of AM that could be regarded as a methodological stage in itself (Horsfield 1998, Walters et al. 2000, Salafsky 2001).

Although we have observed a general application of $\mathrm{AM}$ in all the ecological domains as well as in developed and developing countries, we want to highlight the fact that no AM cases were found in Europe. This is probably due to the deeply-rooted tradition of land management in Europe (EUROPARC 2002), and to the need of managers to count on local populations due to the many natural systems of high value inextricably linked to traditional uses (e.g. cereal steppe lands, or the open woodlands of southern European countries called 'dehesas' in Spain and 'montado' in Portugal).

The greatest differences in the practice of AM between developed and developing countries of our global sample were obtained in the general context, the type of actors involved and some descriptive variables as referred in Table 2. In developed countries, AM is mainly directed to manage natural and socio-economic systems, such as epicontinental waters (Gilmour et al. 1999, Walters et al. 2000, Irwin and Freeman 2002), public use in protected areas
(Lawson et al. 2003), and civil engineering works. Also, the reduction of pollution is another common reason for AM in developed countries, while in developing ones the practice is mainly motivated by the mitigation of environmental impacts associated with mining activities and by protected natural areas management (Fig. 2). These results may be the consequence of a complexity of factors related to the level of economic development of the countries, and also to the criteria used by those who fund and implement AM.

For developed countries, mainly placed in temperate latitudes, the quality and supply of water is of major scientific concern since the 1970s (Ongley 1996). Besides, people in developed countries usually have a high environmental awareness, love to visit protected areas and enjoy natural landscapes, so the issues related to the management of public use, pollution or environmental impacts of civil engineering are of foremost attention. In contrast, in countries with fewer economic resources, mainly belonging to tropical areas, the management is primarily directed to the conservation of their extraordinary biodiversity (very often through the establishment of protected areas in forest ecosystems) and to the restoration of the environmental damage caused by the extractive activities of natural resources. In fact, we found that $\mathrm{AM}$ in protected natural areas is more frequent in developing countries than in developed ones. One striking issue is the practical absence of AM cases on aquatic ecosystems in developing countries, considering that the scarcity of drinking water is a major problem for the population in these countries, as the Millennium Development Goals pointed out (UN 2005). This shows that the implementation criteria of AM in developing countries are influenced by a vision in which conservation of the exuberant nature and the mitigation of environmental impact derived from the exploitation of natural resources are the prevalent criteria. This could be related to the kind of institutions that fund and implement AM projects in both types of countries.

Within our sample of 35 AM cases from 17 different countries all over the world, we found that funding and implementing institutions of AM projects also depend to a great extent on the socio-economic level of the countries where they take place. In developed countries, AM projects are mainly implemented by national organizations with State funding, while in developing countries it is primarily funded by international organizations and private entities. AM is a methodology originally implemented in developed countries, and then transferred to the Third World by the organizations responsible for biodiversity and environmental conservation in developing countries. Here, the lack of sufficient economic resources to face the conservation of biodiversity and of natural resources implies that the management of environment and of natural protected areas is in the hands of conservation groups from richer countries that apply criteria and strategies used at home, amongst them AM. In less developed 
countries the massive extraction of natural resources, especially by mining activities, is mainly carried out by multinationals, usually located in places of high ecological value. In general, these multinationals are lobbied by conservational organizations from their own countries to carry out restoration and mitigation actions, or at least to fund them. This is not the case in developed countries, where the State is responsible for the management of the environment, the natural resources and the natural protected areas, and where most activities target public services (i.e. water supply and civil engineering works) rely on State funding.

Although we cannot extrapolate the results obtained from our global sample to the situation in all countries, we do notice an asymmetry between the AM objectives in developing countries and their compelling environmental needs, especially with reference to water resources. In this sense, we suggest the use of criteria that are customized to the specific needs of the socio-economic reality of each country. This goal could be achieved through a greater collaboration between scientists and managers of both types of countries that would allow the use of sophisticated ecosystem management tools, bearing in mind the true needs of the local population.

The analysis of the present context in AM practice at a global scale has allowed us to identify its main trends and also some gaps that should be faced, mainly related to the management of some natural resources in developing countries. In spite of these "gaps", we agree with Lee (1999) about the enormous possibilities that AM could offer to the sustainable development in developing countries, providing them better life conditions for their people as well as efficient tools to combine development with ecosystem conservation. It should not be forgotten that AM has been identified as a key tool for the Ecosystem Approach strategy, adopted by the Convention on Biological Diversity for the correct management of natural resources (UNEP 2004). Nevertheless, if we consider that most AM cases were at the problem identification stage, we may conclude that it is very important to monitor the results of this management practice at a global scale. This follow-up would tell us about the applicability and efficiency of AM to promote biodiversity conservation and sustainable development, as well as guarantee that AM is more appropriate to solve real problems in developing countries (including types of ecosystem or situations usually considered in developed countries, e.g. water management). All this would render Adaptive Management an even more adaptive process.

Acknowledgements - NZC wants to thank the Spanish Agency for Development and Cooperation for providing financial support to this study through the MAE/AECI Grant entitled "Application of Adaptive Management to Protected Areas of Bioko, Equatorial Guinea". This study was also supported by the Spanish CICYT (grant REN2003-03989/GLO to MAR).

\section{References}

Allen, W. 1997. Improving the role of evaluation within natural resource management $R \& D$ programmes: the case for "learning by doing". - Can. J. Dev. Stud. 18: 629-643.

Allen, W. et al. 2001. Monitoring and adaptive management: addressing social and organisational issues to improve information sharing. - Nat. Resour. Forum 25: 225-233.

Armenteras, D. et al. 2003. Andean forest fragmentation and the representativeness of protected natural areas in the eastern Andes, Colombia. - Biol. Conserv. 113: 245-256.

Bailey, R. 1989. Ecoregions of the continents. - USDA Forest Service.

Blom, A. et al. 2004. Status of the protected areas of the Central African Republic. - Biol. Conserv. 118: 479-487.

BRASS/El Pilar Program 2002. Adaptive management in the Maya forest, field report. - (<http://marc.ucsb.edu/elpilar/ brass/chron/fieldr/report02.pdf $>)$.

British Columbia Forest Service 1996. Definitions of adaptive management. - (<http://www.for.gov.bc.ca/hfp/amhome/ AMDEFS.HTM>).

British Columbia Forest Service 1997. Introductory guide to adaptive management. - (<http://www.for.gov.bc.ca/hfp/ amhome/introgd/intro.htm>).

Bunch, M. 2000. An adaptative ecosystem management approach to rehabilitation and management of the Coocum River environmental system of Chennai, India. PhD thesis. Univ. of Waterloo, Canada.

Burgess, N. et al. 2005. Major gaps in the distribution of protected areas for threatened and narrow range Afrotropical plants. - Biodiv. Conserv. 14: 1877-1894.

California Coastal Commission 2003. Procedural guidance for evaluating wetland mitigation projects in California's coastal zone. - (<http://www.coastal.ca.gov/weteval/wetc.html>).

Campbell, P. et al. 2002. Gabon Biodiversity Program: Biodiversity research, monitoring and training in the Gamba complex, Gabon. - SI/MAB Ser. no. 3; Washington, DC, USA.

Cantú, C. et al. 2004. Assessment of current and proposed nature reserves of Mexico based on their capacity to protect geophysical features and biodiversity. - Biol. Conserv. 115:411417.

Carpenter, S. et al. 1999. Ecological and social dynamics in simple models of ecosystem management. - Conserv. Ecol. 3: 4 (<http://www.consecol.org/vol3/iss2/art4/>).

Comiskey, J. and Dallmeier, F. 2003. Adaptive management: a framework for biodiversity conservation in Takamanda Forest Reserve, Cameroon. - SI/MAB Ser. no. 8; Washington, DC, USA.

Committee on environmental and natural resources (CENR) 2000. Integrated assessment of hypoxia in the Northern Gulf of Mexico. - Natl Sci. Tech. Council Committee on Environ. Natural Resour., Washington.

Costanza, R. et al. 1997. The value of the world's ecosystem services and natural capital. - Nature 387: 253-260.

Dallmeier, F. et al. 2002. Planning an adaptive management process for biodiversity conservation and resource development in the Camisea River Basin. - Environ. Monit. Assess. 76: $1-17$.

De Klerk, H. M. et al. 2004. Gaps in the protected area network for threatened Afrotropical birds. - Biol. Conserv. 117: 529537. 
Dichmont, C. M. et al. 2006. Management strategies for shortlived species: the case of Australia's northern prawn fishery: 1. Accounting for multiple species, spatial structure and implementation uncertainty when evaluating risk. - Fish. Res. 82: 204-220.

EUROPARC-España 2002. Plan de Acción para los espacios naturales protegidos del Estado Español. - (<http:// www.europarc-es.org/intranet/EUROPARC/publicado/ publicaciones_Europarc-Espana/planaccion.pdf $>$ ).

Gilmour, A. et al. 1999. Adaptive management of the water cycle on the urban fringe: three Australian case studies. - Conserv. Ecol. 3: 11 (<http://www.consecol.org/vol3/iss1/art11/>).

Gray, A. N. 2000. Adaptive ecosystem management in the Pacific Northwest: a case study from coastal Oregon. - Conserv. Ecol. 4: 6 (<http://www.consecol.org/vol4/iss2/art6/>).

Gregory, R. et al. 2006. Desconstructing adaptive management: criteria for applications to environmental management. Ecol. Appl. 16: 2411-2425.

Hering, K. 2003. A scientific formulation of tropical forest management. - Ecol. Modell. 166: 211-238.

Holling, C. S. 1978. Adaptive environmental assessment and management. - Wiley.

Horsfield, R. 1998. Benchmarks for assessing environmental management practices against an "ideal" Adaptive Environmental Assessment and Management Protocol. - (<http:// www.gse.mq.edu.au/Research/adaptive/report1.htm>).

Innu Nation 1995. Adaptive mismanagement proposed for nitassinan forests. - (<http://www.innu.ca/adaptivemm.html $)$.

Irwin, E. and Freeman, M. 2002. Proposal for Adaptive Management to conserve biotic integrity in a regulated segment of the Tallapoosa River, Alabama, USA. - Conserv. Biol. 16:1212-1222.

Jepson, P. et al. 2002. A review of the efficacy of the protected area system of east Kalimantan Province, Indonesia. - Nat. Areas J. 22: 28-42.

Johnson, F. and Williams, K. 1999. Protocol and practice in the adaptive management of waterfowl harvests. - Conserv. Ecol. 3: 8 (<http://www.consecol.org/vol3/iss1/art8/>).

Karnella, C. et al. 2003. Adaptive management of monk seals in the main Hawaiian Islands. Workshop on the management of Hawaiian monk seals on beaches in the main Hawaiian Islands. Final report. - Mar. Mamm. Commission Natl Mar. Fish. Service Hawaii Div. Aquat. Resour. USA, pp. 1-22.

Latif Khan, M. et al. 1997. Effectiveness of the protected area network in biodiversity conservation: a case-study of Meghalaya state. - Biodiv. Conserv. 6: 853-868.

Lawson, S. et al. 2003. Proactive monitoring and adaptive management of social carrying capacity in Arches National Park: an application of computer simulation modelling. - J. Environ. Manage. 68: 305-313.

Lee, K. N. 1999. Appraising adaptive management. - Conserv. Ecol. 3: 3 (<http://www.consecol.org/vol3/iss2/art3/>).

Lynam, T. 1999. Adaptive analysis of locally complex systems in a globally complex world. - Conserv. Ecol. 3: 13 (<http:// www.consecol.org/vol3/iss2/art13/>).

Lynam, T. et al. 2002. Adapting science to adaptive managers: spidergrams, belief models, and multi-agent systems modelling. - Conserv. Ecol. 5: 24 (<http://www.consecol.org/vol5/ iss2/art24/>).

McCune, B. and Mefford, M. J. 1999. PC-ORD multivariate analysis of ecological data, ver. 4.25. - MjM Software, Gleneden Beach, Oregon, USA.
McGinley, K. and Finegan, B. 2003. The ecological sustainability of tropical forest management: evaluation of the national forest management standards of Costa Rica and Nicaragua, with emphasis on the need for adaptive management. - For. Policy Econ. 5: 421-431.

McLain, R. J. and Lee, R. G. 1996. Adaptive management: promises and pitfalls. - Environ. Manage. 20: 437-448.

Merenlender, A. et al. 1998. Monitoring impacts of natural resource extraction on lemurs of the Masoala Peninsula, Madagascar. - Conserv. Ecol. 2: 5 (<http://www.consecol.org/ $\operatorname{vol} 2 /$ iss $2 / \operatorname{art} 5 />)$.

Nyberg, B. 1999. An introductory guide to adaptive management for project leaders and participants. - BC Forest Service, Canada.

Oldfield, T. et al. 2004. A gap analysis of terrestrial protected areas in England and its implications for conservation policy. - Biol. Conserv.120: 303-309.

Ongley, E. D. 1996. Control of water pollution from agriculture. FAO irrigation and drainage paper 55. - FAO, UN, Rome (< h t t p : / / w w w.fao.org/docrep/W $2598 \mathrm{E} /$ w2598e00.htm\#Contents $>$ ).

Pinkerton, E. 1999. Factors in overcoming barriers to implementing co-management in British Columbia salmon fisheries. - Conserv. Ecol. 3: 2 (<http://www.consecol.org/vol3/ iss $2 / \operatorname{art} 2 />$ ).

Powell, G. et al. 2000. Assessing representativeness of protected natural areas in Costa Rica for conserving biodiversity: a preliminary gap analysis. - Biol. Conserv. 93: 35-41.

Salafsky, N. et al. 2001. Management effectiveness initiative. Adaptive management: a tool for conservation practitioners. WCPA-Marine/WWF MPA (<http://effectivempa.noaa.gov/ docs/adaptive.pdfs).

Shindler, B. and Cheek, K. A. 1999. Integrating citizens in adaptive management: a propositional analysis. - Conserv. Ecol. 3: 9 (<http://www.consecol.org/vol3/iss1/art9/>).

Smithsonian Institution 2003. Monitoring and assessment of biodiversity program. - (<http://nationalzoo.si.edu/ConservationAndScience/MAB/>).

Statsoft. Inc. 2003. STATISTICA (data analysis software system) ver. 6. - (<http://www.statsoft.com>).

Struhsaker, T. et al. 2005. Conserving Africa's rain forests: problems in protected areas and possible solutions. - Biol. Conserv. 123 : $45-54$.

Sunderland, T. et al. 2003. Future conservation and management of the Takamanda Forest Reserve, Cameroon. - SI/MAB Ser. no 8; Washington, DC, USA.

The Seal of Pima County 2001. The role of adaptive management in the Sonoran Desert Conservation Plan. - (<http:// www.pima.gov/cmo/sdcp/reports/d9/011ROL.PDF>).

IUCN 1994. Guidelines for protected areas management categories. - IUCN, Cambridge, UK.

Toledo, V. M. et al. 2003. The multiple use of tropical forests by indigenous peoples in Mexico: a case of adaptive management. - Conserv. Ecol. 7: 9 (<http://www.consecol.org/vol7/ iss3/art9>).

UN 2005. The millennium development goals report. - UN Dept of Public Inf. DPI/2390, New York.

UNDP 2002. Human development report 2002. - Oxford Univ. Press.

UNEP 2004. Seventh ordinary meeting of the conference of the parties to the convention on biological diversity. - Kuala Lumpur, Malaysia. 
US Forest Service 2003. - FEIS Adaptive Management Strategy 4, Appendix E-i.

Walters, C. J. and Holling, C. S. 1990. Large-scale management experiments and learning by doing. - Ecology 71: 20602068.

Walters, C. 1997. Challenges in adaptive management of riparian and coastal ecosystems. - Conserv. Ecol. 1: 1 (<http:// www.consecol.org/vol1/iss2/art1/>).

Walters, C. et al. 2000. Ecosystem modelling for evaluation of adaptive management policies in the Grand Canyon. -
Conserv. Ecol. 4: 1 (<http://www.consecol.org/vol4/iss2/ $\operatorname{art} 1 />)$.

Wilkie, D. et al. 2001. The under-financing of protected areas in the Congo Basin: so many parks and so little willingness-topay. - Biodiv. Conserv. 10: 691-709.

Zimmerman, K. et al. 2000. An inventory of ecological factors affecting northern caribou in the Omineca Region, British Columbia: Year 2 (1999), inventory results. - BC Min. Environ., Lands and Parks, Omineca Region, Prince George, BC, Canada. 